\title{
Is there a Central Andean Linguistic Area? A View from the Perspective of the "Minor" Languages
}

\author{
Matthias Urban \\ Eberhard Karls Universität Tübingen, Germany \\ matthias.urban@uni-tuebingen.de
}

\begin{abstract}
In this article, I reconsider the evidence for a Central Andean linguistic area. I suggest that there is no evidence for a clear-cut linguistic area comprising the entire Central Andes narrowly defined, and that perceived homogeneity is partially due to an overemphasis on the largest and surviving Central Andean language families, Quechuan and Aymaran. I show that none of the other Central Andean languages known sufficiently well match their typological profile to a high degree. I make a contribution to a more adequate picture by discussing some typological aspects tentatively recoverable for the extinct and poorly documented languages of the North-Central Andes. These suggest that the North was the site of linguistic traits contrasting with those of Quechuan and Aymaran.
\end{abstract}

\section{Keywords}

Central Andes - language area - Quechuan - Aymaran

Pre-Hispanic language contact has decisively shaped the linguistic landscape of the Americas. In some areas, language contact has resulted in recognizable convergence in linguistic structures, leading to areal patternings of phonological and grammatical properties across genealogical boundaries. Well-known examples are the Northwest Coast of North America (e.g. Thomason, 2014) and Mesoamerica (Campbell et al., 1986). As far as South America is concerned,

(C) MATTHIAS URBAN, $2019 \mid$ DOI:10.1163/19552629-01202002

This is an open access article distributed under the terms of the prevailing CC-BY-NC License at the time of publication. 
Dixon and Aikhenvald (1999: 8-10) suggest that many Amazonian languages share certain traits that can be used to identify Amazonia in its entirety as one large linguistic area. This proposed Amazonian area contrasts, according to Dixon and Aikhenvald (1999: 8-10), with a distinct, almost equally large language area in the Andes, even though the features characterizing the two areas "tend to flow into each other" (Dixon and Aikhenvald, 1999: 10). In effect, this would mean that in South America one is dealing with two very large linguistic areas that together cover a significant proportion of the entire (sub)continent. ${ }^{1}$

The unprecedented surge of efforts to document South America's indigenous languages in the past 20 years or so has yielded a rapid growth in knowledge of linguistic structures at an increasingly finer level of granularity. This concerns particularly the dazzling linguistic diversity of the Amazonian lowlands. As new primary descriptive information is becoming available, South American areal linguistics is also making significant progress. By now, there is a large amount of literature on language contact and linguistic convergence in parts of Amazonia. Some contact scenarios and settings have been studied in detail on the basis of intensive linguistic fieldwork (e.g. Aikhenvald, 2002). In addition, distinct regional interaction spheres that differ from one another in ways that may be related to social practices are now recognized (cf. Epps, in press for the most recent survey). Thus, research at different levels of scale (cf. Muysken, 2008: 5, Table 1) now paints a nuanced and relatively detailed picture of language contact and its effects in the Amazonian lowlands.

In this article, I shift the focus of attention from Amazonia, which -as just outlined- is experiencing significant progress in the elucidation of areal structures, back to the Andes, which are still commonly regarded as an areal-typological monolith. In dialogue with and sometimes in contrast to the

1 The proper definition and ontological status of linguistic areas or Sprachbünde is a continuing issue in contact linguistics (cf. e.g. Stolz, 2002 and Campbell, 2006). While I am perfectly aware of these complications, for the purpose of the present paper, which is concerned with the empirical validity of a specific linguistic area in the Andes postulated by Dixon and Aikhenvald (1999: 8-10) and Aikhenvald (2007), I largely bypass them by simply following these authors' own rather straightforward definition. Dixon and Aikhenvald (1999: 8) say that a linguistic area involves "languages from several different genetic groups" which share "certain symptomatic features" -typologically common ones having less diagnostic value than rare ones- that are not found in languages from these genetic groups outside the area. 
existing literature, I reconsider the Central Andes in particular. As defined here, this area geographically "stretches from roughly the Peru-Ecuador border in the north, to the low forests of Peru and Bolivia in the east, and south to the southern part of the Titicaca Basin in Bolivia" (Stanish, 2001: 41). This geographical delimitation is socioculturally motivated. The site of the so-called Central Andean co-tradition (Isbell and Silverman, 2008), it is one of the few areas in the world where complex civilization developed independently of outside influences. There are at least two centers of gravity in terms of cultural development. One is the North Coast of Peru, which is characterized by a more or less continuous cultural trajectory from the $3^{\text {rd }}$ millennium $\mathrm{BC}$, when the first monumental architecture at Cerro Ventarrón was built (Alva Meneses, 2008). The other center of gravity is located in the southern highlands, home to cultures like Wari, Tiwanaku, and ultimately the Inca, who would expand their empire to incorporate the southern highlands, the North Coast, and lands far beyond. ${ }^{2}$

The Central Andes are at the same time the part of the Andean mountain chain that is responsible for the idea of an Andean linguistic area characterized by relative typological homogeneity, and hence of particular interest for the theorizing of South American areal linguistics generally. This has much to do with the presence of just two shallow but widespread language families with intimately linked histories, Quechuan and Aymaran. The main aim of this article is to demonstrate that the Central Andes as just defined were probably originally more typologically diverse than the present-day dominance of Quechuan and Aymaran languages suggests. Just like Amazonia today, in preHispanic times the Central Andes may have hosted more regional networks of linguistic affinities.

2 In contrast to the present approach, sociocultural calibration points for geographical partitioning of the Andes are indeed often derived from the maximum extent of the Inca empire, the last cultural expression of the Andean cultural trajectory before the arrival of the Spanish invaders. This definition is used in both archaeology and linguistics (Quilter, 2014: 2; Adelaar, 2012a: 576). The Central Andean area defined in this way then incorporates the Ecuadorian coast and highlands up to southernmost Colombia in the north, and northern Chile and Argentina in the south. However, Inca presence in regions like the North Coast of Peru and Ecuador (where it was much stronger in the highlands; see Stothert, 2013 for details) was a short-lived episode in Andean prehistory, lasting for at most 100 years; it contrasts with a much older (though not static or impermeable) cultural divide between Ecuadorian and Peruvian cultural spheres and is therefore without precedent in Andean prehistory. 
To make my case, I will first discuss, in the next section, the Quechuan and Aymaran language families, their mutual relationship and resulting common typological profile, and the role they have played in theorizing linguistic areality in the Andes and South America more broadly. I also outline the diverse linguistic landscape in which these larger language families were embedded in pre-Hispanic times. In section three, I embark on a detailed reevaluation of traits claimed to characterize the Andes as opposed to Amazonia, with particular reference to the work of Dixon and Aikhenvald (1999) and Aikhenvald (2007). This reevaluation demonstrates that while many of these traits indeed characterize Quechuan and Aymaran, they do not characterize other Central Andean languages so well, or even at all. As I argue in section four, the typological commonalities between Quechuan and Aymaran are not necessarily the only meaningful observations that can be made regarding the areal linguistics of the Andes. On the contrary, I suggest that the North-Central Andes may have been a site of linguistic convergence involving more local languages that are not related genealogically to Quechuan and Aymaran. This, in turn, is evidence for a patchwork of more localized zones of convergence in the Central Andes as well. I conclude the article in section five with some general remarks and suggestions as to the relevance of its conclusions for the interdisciplinary theorizing of Andean prehistory.

\section{Quechumara and the Andean Language Type}

\subsection{Quechuan, Aymaran, and their Typological Profile}

Today, the Central Andes as defined in the introduction are dominated by languages belonging to the Quechuan and Aymaran families. Quechuan and Aymaran are the largest language families of the Central Andes in terms of number of speakers and geographical spread, but their internal diversity is rather modest; at the same time, they are also by far the best-studied Andean language families.

The Quechuan languages are found in enclaves in Northern Peru and Argentina, and are widely spoken in the highlands of Ecuador, Central and Southern Peru, and Bolivia. Quechuan varieties are also found in parts of the eastern lowlands of Ecuador and Peru. This distribution largely goes back to preHispanic times. The map in Fig. 1 shows the probable Quechuan-speaking areas of the Central Andes (as defined in the introduction) at the point of European contact, in dark shading.

A consensus classification of the Quechuan family, based on CerrónPalomino (1987: 247), can be seen in Figure 2. Genealogical subgroups are in 


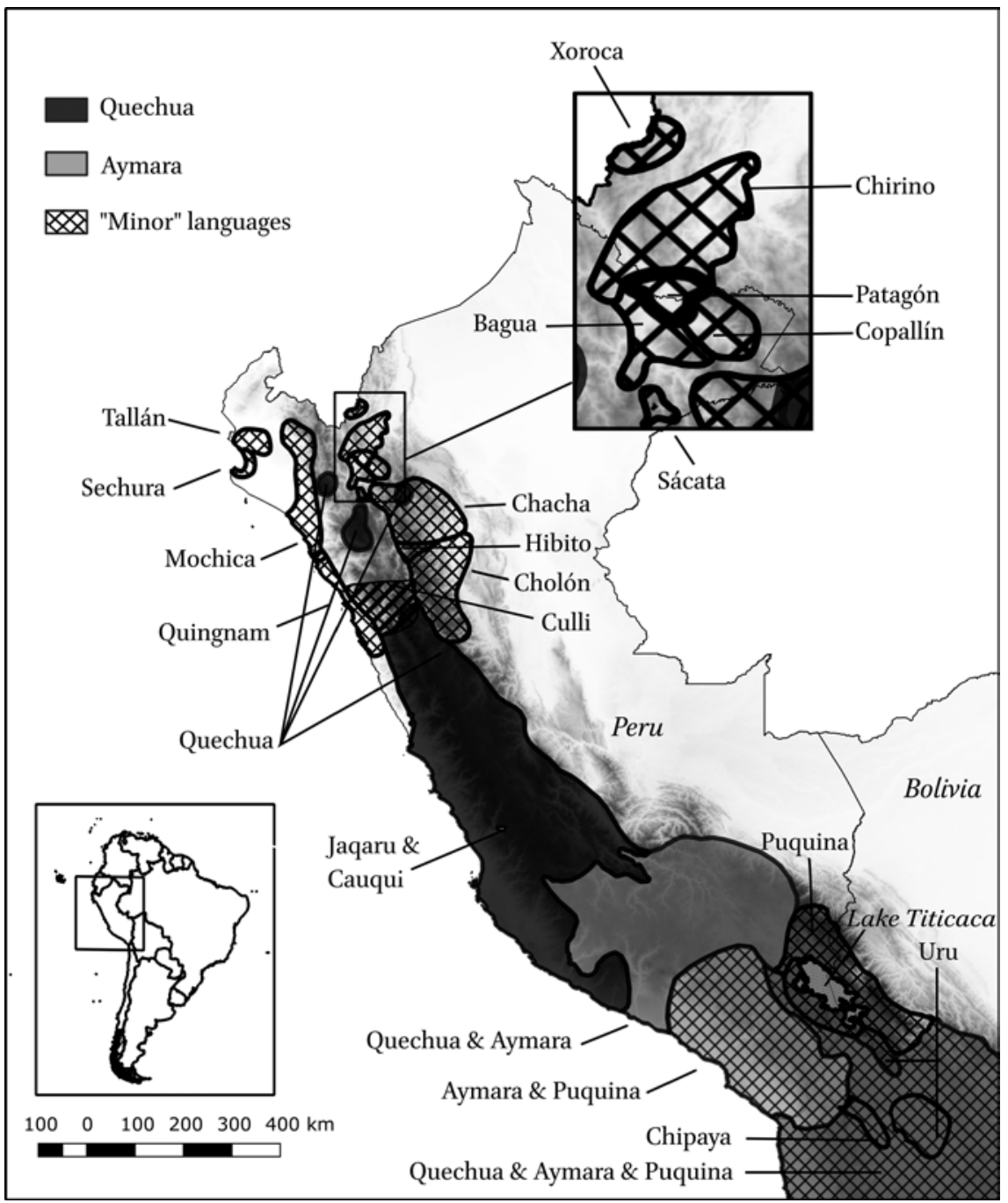

FIGURE 1 A reconstruction of the linguistic situation in the Central Andes at the point of European contact, based on Cerrón-Palomino (2010), Urban (2019), and Torero $(1986,1990,1993)$. The figure is for illustration purposes only; all linguistic boundaries shown are approximate and lowland languages further east are not shown.

regular type, while individual varieties (traditionally called "dialects" in Quechuan studies, though not necessarily mutually intelligible) are in italics. It should be pointed out, however, that the basic split into Huaihuash (Quechua I) and Huampuy (Quechua II) varieties has been a subject of recent debate (Heggarty and Pearce, 2011 vs. Adelaar, 2013), and the validity of the Yungay (IIA) subgroup is also questionable. 


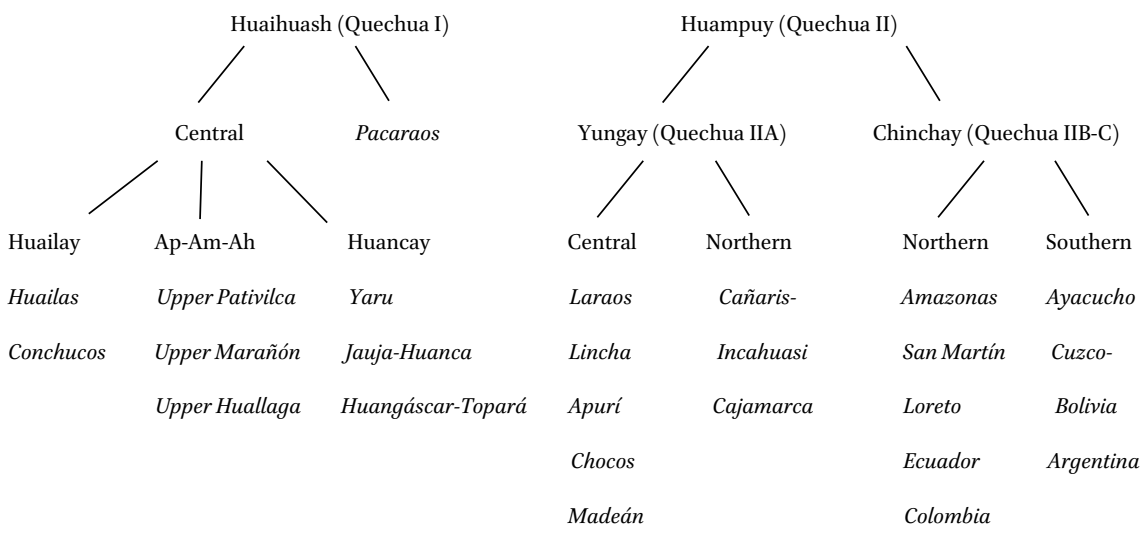

FIGURE 2 Consensus classification of the Quechuan languages, adapted from CerrónPalomino (1987: 247).

The internal structure of the Aymaran language family is much simpler than that of Quechuan. Essentially, it consists of Aymara proper (with various dialects), which is spoken in the Andean highlands of Southern Peru and Bolivia. A sister branch, consisting of the very closely related and seriously endangered varieties Jaqaru and Cauqui, survives in a small region of Central Peru's Lima department (see Fig. 1). This is almost certainly a relic zone. Together with evidence from toponymy, its existence suggests a much wider distribution of the Aymaran family at some earlier point in prehistory (cf. Adelaar with Muysken, 2004: 171).

Quechuan and Aymaran bear a peculiar relationship to each other. There is a high degree of structural isomorphism in the grammars (cf. e.g. CerrónPalomino, 1994; Adelaar, 2017) and a high degree of shared vocabulary (cf. e.g. Emlen, 2017). Both grammatical and lexical similarities reconstruct to the respective proto-languages, to the effect that a genealogical relationship was long considered possible or likely. In recent years, however, the pendulum has been increasingly swinging back to the alternative position, according to which the similarities are not due to common descent, but rather to intensive language contact that must go back to the respective proto-languages (Adelaar, 2010, 2012b; Emlen, 2017) and has continued at more local levels in several places, in particular in Southern Peru. The label "Quechumara", earlier applied to the hypothetical language family comprising both Quechuan and Aymaran (Mason, 1950: 196), has been accordingly redefined to refer to the shared characteristics of the Quechuan and Aymaran languages (Cerrón-Palomino, 1994). This usage is followed in the present article. 
Given that the initial convergence (Adelaar's 2012b term) must have taken place in prehistoric times, from which no written records are available, the sociolinguistic parameters that would make it possible to estimate rates of bi- (or multi-)lingualism and intensity of contact are not directly available and must be inferred. Adelaar (2012b: 465) imagines the invasion of speakers of an ancestor of proto-Quechua into the territory occupied by people whose language ultimately gave rise to the Aymaran lineage, and their subsequent coexistence. A compelling complemental or alternative scenario, developed by Urton (2012), suggests that the relationship between the Quechuan and Aymaran languages is linked to two complementary social identities: that of agriculturalists in the fertile intermontane valleys of the high Andes and that of camelid pastoralists hailing from the still higher dry grasslands. Both scenarios are compatible with intensive and stable bilingualism, which must be posited post hoc to account for the profound interrelatedness of Quechuan and Aymaran. Indeed, it is almost certain that significant portions of the South-Central Andes were bilingual at the point of European contact (cf. Map 1 and the relevant source, i.e. Cerrón-Palomino, 2010).

Quechuan and Aymaran within the Pre-Hispanic Linguistic Diversity of the Central Andes

Underlying the Quechuan and Aymaran linguistic "horizon", however, there is a partially obscured picture of linguistic diversity in the Central Andes: while perceived today as the indigenous languages par excellence, in many regions of Andean South America, Quechuan varieties in reality acted as "killer language[s]", ousting previous diversity, as Adelaar (2007: 326) observes. Even in the South-Central Andes, the relatively homogeneous linguistic landscape dominated by Quechuan and Aymaran is arguably to some extent due to distortions in colonial times (Mannheim, 1991; Durston, 2007). Prior to European impact, Quechuan may have been just one prominent group of languages among many. As recently as colonial times, Quechuan coexisted with the Puquina language, which was once not only widespread in the highlands of Southern Peru, but also had a presence in the Pacific lowlands near or on the coast. According to Cerrón-Palomino (2010), Puquina coexisted with Quechuan and Aymaran in extensive parts of the southern Central Andes (cf. also Figure 1). Its extinction in the early $19^{\text {th }}$ century (cf. Adelaar and van de Kerke, 2009: 125) and the scant documentation, virtually restricted to Oré (1607), leave much of the Puquina lexicon undocumented and the picture that can be obtained for the grammar very incomplete. What can be learned is sketched in Adelaar and van de Kerke (2009). Parts of the grammar and some lexical items suggest a 
relation of some sort with the Arawakan language family. The southern fringe of the study area, around Lake Titicaca, was the home of the Uru-Chipayan languages (see Figure 1). Chipaya is the sole survivor and best-known language of this small family (Cerrón-Palomino, 2006; Cerrón-Palomino and Ballón Aguirre, 2011).

In addition, in the North-Central Andes, where the presence of Quechuan and Aymaran appears to have been relatively weak throughout the historical era, languages that were documented in colonial times by Spanish grammarians are Mochica on the North Coast (de la Carrera, 1644) and Cholón (de la Mata, 1748/2007) on the eastern slopes of the Andes. It is widely but not generally agreed that Cholón had a closely related sister language, Hibito, with which it formed a small family (cf. Adelaar with Muysken, 2004: 461 and Torero, 1986: 533 for the alternative position). Mochica has so far resisted genealogical classification and must be considered an isolate. The colonial grammars for Mochica and Cholón have been the subject of renewed attention in recent decades (Cerrón-Palomino, 1995; Torero, 2002; Hovdhaugen, 2004 for Mochica; Alexander-Bakkerus, 2005 for Cholón), with the effect that the phonology and grammars of the languages can now be largely reconstituted in terms of modern linguistics, even though ambiguities and unclarities remain. Mochica and Hibito-Cholón, however, are just the tip of the iceberg of a massively diverse linguistic landscape that featured a multitude of still more poorly documented languages on the coast, in the highlands, and on the eastern slopes of the northern Peruvian Andes. Figure 1 shows an approximate reconstruction of the situation at the point of European contact. Yet this diversity was ousted, partly by a shift to Quechua in pre-Hispanic times, and then by a shift to Spanish at various points in time between the $16^{\text {th }}$ and $20^{\text {th }}$ centuries. Languages of the Peruvian North Coast include not only Mochica in the upper Piura valley and the coastal zones of the Lambayeque department and the northern La Libertad department, but also Tallán and Sechura in today's Piura department, and Quingnam (or Pescadora) from the southern La Libertad department southward. Tallán and Sechura are documented through short wordlists (Martínez Compañón, [1782-1790]1985; Spruce in Urban, 2015), while Quingnam is essentially undocumented, apart from a list of numerals that can likely be attributed to the language (Quilter et al., 2010). The hitherto most thorough analysis of Tallán, Sechura, and Quingnam, also adducing ancillary sources such as indigenous placenames and regional vocabulary, is in Urban (2019). In the adjacent highlands, there were two undocumented languages only recognizable through characteristic toponymic endings, after which they are named "Den" and "Cat" by Torero (1989). Further to the south, the northern highlands were the domain of the Culli language, also principally 
known through two short wordlists (Martínez Compañón, [1782-1790]1985; Rivet, 1949). Culli has received ample scholarly attention in recent years (cf. Andrade Ciudad, 2010 for an overview and further references). To the east of the Marañón valley, where altitude starts to decrease as the Andes give way to more tropical lowlands, different languages again were spoken, including both Hibito-Cholón and the undocumented Chacha, the original language of the Chachapoyas region before the advent of Quechuan. Taylor (1990) assembles and evaluates the available data -mainly personal names and placenames- for Chacha. A true harbor of linguistic diversity was the area of Jaén, where as many as nine distinct languages were spoken in an area approximately the size of the Netherlands. Known only through very few words each, an Amazonian affiliation can be suggested for some of these languages (Torero, 1993).

Although the available materials for the northern languages other than Mochica and Cholón have also been the subject of increased scholarly attention, the relationship between these languages is not yet well understood. As I argue in Urban (2017), shared basic vocabulary in what appear to be otherwise genealogically unrelated languages and certain typological affinities, which are discussed in more detail in section 3, suggest that at least a significant subset of the population was bi- or multilingual in pre-Hispanic times and engaged in long-standing patterns of interaction.

\section{Reassessing Quechumara within the Areal Typology of the Central} Andes

As already mentioned in the introduction, it has been claimed that the Andes host a linguistic area. Aikhenvald (2007: 192), building on earlier work by Dixon and Aikhenvald (1999), proposes a distinction between an "Amazonian" linguistic type and an "Andean linguistic area [...] which comprises the Quechua and Aymara families", and provides a tabular overview of proposed diagnostic criteria that distinguish between the languages of these areas (Aikhenvald 2007: 193, Table 10.1). This table is reproduced here verbatim as Table 1.

Some fine-grained typological work has by now been done not only for Amazonia, but also for the Andes (Torero 2002: 518-544; Adelaar, 2008, 2012a; van de Kerke and Muysken, 2014). However, "Andean" linguistic features are sometimes still defined explicitly as those found in Quechuan or Aymaran (e.g. Valenzuela, 2015: 12). Even though Torero (2002: 518) criticized the statements in Dixon and Aikhenvald (1999) as Quechumaracentric (while not 
TABLE 1 Profiles of "Lowland Amazonian" and "Andean" languages, according to Aikhenvald (2007: 193, Table 10.1).

Lowland Amazonian

(a) The majority of languages are polysynthetic and head marking; agglutinating with little fusion.

\section{Andean}

Andean languages are synthetic, and combine head and dependent marking; basically agglutinating with some fusion (subject, object, and tense suffixes to the verb may be fused).

(b) Typically one liquid phoneme, which is frequently a flap; usually more affricates than fricatives. The high unrounded central vowel $\dot{i}$ is frequent. A typical Amazonian vowel system has five members: i, e, a, $\dot{i}, \mathrm{u} / \mathrm{o}$. There is typically contrastive nasalization of vowels.

(c) Many languages have extensive classifier and/ or gender systems. Gender assignment is often semantically transparent, and is not overtly marked on the noun.

(d) There are few oblique cases (often a locative and an instrumental/comitative), but hardly any core cases.

(e) Just one core argument is typically crossreferenced on the verb. There may be different bound pronominal paradigms depending on which core argument is being cross-referenced in each particular instance.

$(f)$ The rules for which core argument is crossreferenced can be complex (relating to the meaning of the verb, clause type, etc.) often giving rise to a "split-ergative" system. Fully accusative systems of marking for predicate arguments are rarely encountered.

(g) Most (although not all) languages have prefixes; there are typically fewer prefix than suffix positions.

(h) There is generally only a small class of lexical numbers.
Two or three liquids; fricatives rather than affricates; and a three-vowel system i, a, and $u$, with no contrastive nasalization.

No genders or classifiers.

Extensive set of core and oblique case markers.

Two core arguments are marked on the verb.

Fully nominative/accusative systems.

No prefixes.

Full set of lexical numbers 
actually providing extensive discussion to bolster the claim), the monolithic view of the Andes as linguistically characterized by Quechuan and Aymaran is thus still prominent. In a footnote, however, Aikhenvald (2007: 192) herself cautions: "Whether Quechua and Aymara belong to the same linguistic type as other languages spoken outside the Amazonian Lowlands (such as Mapuche, Leko, Cholón and Uru-Chipaya) is an open question." This, in fact, strongly suggests that the "Andean" area does not just comprise, but is actually defined with reference to Quechuan and Aymaran. In the following, I set out to investigate the question as to the typological affiliation of the non-Quechuan, nonAymaran languages of the Central Andes as defined above. In particular, I aim to elucidate whether, and if so to what extent, the Quechumara typological prototype fits these languages. In doing so, I will use the same criteria that have been proposed by Aikhenvald (2007), beginning with the overall typological characterization (feature $(a)$ ) and phonological properties (feature $(b)$ ), and then moving into morphosyntax (features $(c)-(g)$ ) and the lexicon, numerals in particular (feature $(h)) .^{3}$

Typological characteristics of Quechuan and Aymaran can be compared with those of the neighboring Uru-Chipayan languages and at least tentatively with the extinct Puquina. In addition to these, typological comparisons can also be made with Cholón and Mochica, from the Northern Peruvian Andes. These genealogical groupings and isolates -Quechuan, Aymaran, Hibito-Cholón, Uru-Chipayan, Mochica, and sometimes Puquina- are the ones usually considered in areal studies of the Central Andes. This is because they are the only ones with sufficient documentation for typological comparisons to be carried out over a wide range of phonological and grammatical features. The same set of languages is accordingly investigated here, on the basis of my own knowledge and aided by Cerrón-Palomino (2003) and Adelaar with Muysken (2004) for Quechuan; Hardman (2001) for Aymaran; Adelaar with Muysken (2004) and Cerrón-Palomino (2006) for Chipaya; Adelaar and van de Kerke (2009) for Puquina; Hovdhaugen (2004) for Mochica; and AlexanderBakkerus (2005) for Cholón.

3 Dixon and Aikhenvald (1999: 10) in fact mention several other "Andean" characteristics: "possession is marked both on possessor and on possessed", "bound pronominal markers of possession show some similarity to, but are not identical with, the forms marking core arguments on the verb", "an obligatory suffixal system for tense and aspect", "[s]ubordination does not involve nominalization", and "no incorporation of nouns, adverbs or prepositions." I do not evaluate these earlier statements systematically here and focus instead on Aikhenvald's (2007) more recent statement. However, such an evaluation would not greatly alter the overall conclusions. 


\subsection{Overall Typological Profile (Feature $(a)$ )}

Aikhenvald's feature $(a)$ is concerned with an overall characterization of Andean languages in terms of morphological typology (e.g. Comrie, 1989) and the locus of marking (Nichols, 1986). Andean languages are described as "synthetic." This is a claim that is hard to evaluate objectively without carrying out quantitative procedures such as those in Greenberg's (1960) classic operationalization. Suffice it to say that if Quechuan and Aymaran are characterized impressionistically as "synthetic", then at least Mochica would likely have to be regarded, equally impressionistically, as significantly "less synthetic" when the affixation potential as a whole is considered. Examples in (1.) a-f may give the reader an impression of the morphosyntactic differences between the languages of the Central Andes under scrutiny. ${ }^{4}$ Regarding head and dependent marking, it is true that all the languages surveyed feature elements of both; radically head-marking languages are absent from the Central Andes.

(1.) a. TARma QuechuA (adapted from Adelaar, 2017)

na:- $\quad$ mi serbi- ra- ma- nki sapatu qu- nqa- $q$ uša- nqa- $n^{-} \quad$ gama already- Ass serve- PFV- 1 OBJ- 2SBJ shoe give- NMLZ- $1>2$ finish- NMLZ- 3SBJ- LIM 'You have already served me long enough to wear out the shoes that I gave to you.'

b. Muylaque Aymara (Coler, 2014: 438)

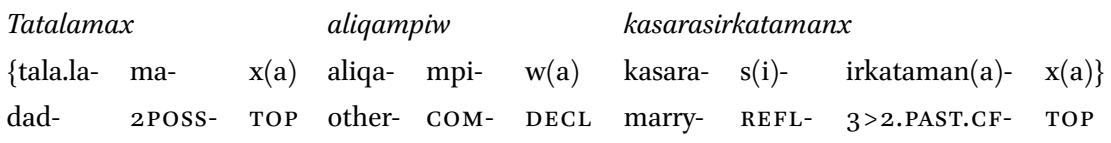

'Your dad should have married you to someone else.'

4 Some minor changes have been made in segmentation and glossing; in addition, abbreviations in glosses have been standardized according to the Leipzig Glossing Rules (https:// www.eva.mpg.de/lingua/pdf/Glossing-Rules.pdf). Remaining non-standard glosses include ASs 'assertive', LIM 'limitative', CF 'counterfactual', SM 'simultaneous', Ds 'different subject', and SR 'switch reference'. The Aymara example has an additional line for morphophonemic representation because of the ubiquitous vowel deletion rules, which obscure morpheme shapes on the surface. Puquina and Mochica data retain the orthography of the colonial source and are therefore enclosed in $<$ chevrons $>$. 
c. Chipaya (adapted from Adelaar with Muysken, 2004: 373)

wer $=\stackrel{s}{s} \quad$ u:ša kon- nan we- $t$ hila- $k i$ ton $=\check{c}^{-} i^{-} \quad \check{c} a$

$1 \mathrm{SG}=3 \mathrm{SG} . \mathrm{M}$ sheep kill SM.DS 1 SG- GEN brother- TOP come $=3$ SG.M.PST- DECL

'When I was killing the sheep, my brother arrived.'

d. Puquina (adapted from Adelaar and van de Kerke, 2009: 135)

$<$ mutu- que- guina $>$

suffer- $\quad$ APPL- $\quad 1(>2)$.FUT $)$

'I will suffer with you', 'I will help you to suffer'

e. MochicA (adapted from Hovdhaugen, 2004: 30)

$\begin{array}{llllllll}<\text { tzha.c- } & n & \text { moin } & \text { tzceng } & \text { cuçia- } & \text { s.- } & e= & \text { nic }> \\ \text { carry- } & \text { IMP } & \text { 1SG.NOM } & \text { 2SG.OBL } & \text { heaven } & \text { POSS } & \text { OBL }= & \text { LOC/ALL } \\ \text { 'Carry me to your heaven!' } & & & & & \end{array}$

f. Cholón (adapted from Alexander-Bakkerus, 2005: 334)

$\begin{array}{llllllllll}i- & t^{s i p-} & t e & i- & t o y- & h u & a- & p o- & y c^{-} & i y \\ \text { 3PL.POSS- } & \text { house- } & \text { LOC } & \text { 3PL.SBJ- } & \text { be- } & \text { SR } & \text { 1 SG.A- } & \text { 3PL.OBJ- } & \text { see- } & \text { PST }\end{array}$

'I saw them in their houses.'

Finally, Andean languages are characterized by Aikhenvald (2007) as "basically agglutinating", though with "some fusion", in particular regarding "subject, object, and tense suffixes to the verb." It is true that Quechuan and Aymaran languages exemplify what has been called the agglutinating language type just as clearly as the classic example, Turkish. However, Aikhenvald's statement seems to refer to the redefinition of the concept of agglutination as found in Comrie (1989), for example, where agglutination-fusion forms one of the two axes of morphological typology and there is no reified language type called "agglutinating." The characterization is accurate for Quechuan and Aymaran, and notably also for Puquina (Adelaar and van de Kerke 2009: 131). Beyond these languages, the picture becomes more muddled. In Chipaya, the choice of tense-aspect suffixes is sensitive to grammatical categories including person and number of the subject (Adelaar with Muysken, 2004: 370), but the picture is different in that there appears to be no verbal person marking proper in the language. In Cholón, personal reference markers and tense affixes do not fuse 
(and they could not, as they appear on different sides of the verb stem, cf. if). The morphosyntactic status of personal reference markers in Mochica is a vexed issue. However, there is no evidence for tense and person markers fusing in a systematic fashion (although there is some fusion elsewhere).

\subsection{Phonology (Feature (b))}

The characterization of the languages of the Central Andes as having "[t]wo or three liquids" is largely correct. A salient observation, however, is that most Quechuan varieties, as well as the proto-language, featured $* / K /$, but that $* / 1 /$ was at best marginal, if existent at all (Adelaar with Muysken, 2004: 195). ${ }^{5}$ Thus, the statement "two or three liquids" suggests some sort of typological normality, when in fact the quality of the liquids present can be highly unusual. In addition, not all Central Andean languages are accurately characterized as having two or three liquids: Chipaya may have as many as four. In general terms, however, the contrast with the paucity of liquids in Amazonia -usually just one, according to Aikhenvald-is certainly valid.

As far as the vowel system is concerned, it is correct that Andean languages lack contrastive nasalization in vowels. Otherwise, however, Aikhenvald's (2007) characterization of Andean languages as featuring "a three-vowel system i, a, and u" presents the clearest evidence for too strong a Quechumara influence on the picture. Such a system is indeed found in many Quechuan and all Aymaran varieties, but not in Chipaya, Puquina, Mochica, or Cholón, nor in any of the adjacent languages in the south (see section 4 on Culli). All have vowel systems of five or six vowels. In addition, under some analyses, not even all Quechuan varieties are trivocalic. In some cases, this is due to a rather superficial layer of Spanish loanwords on the basis of which mid-vowel contrasts have been introduced. In others, such as Ancash and Chachapoyas Quechua, mid-vowels may arise as the result of simplification of the sequences /ay/and /aw/, though the question of whether these are underlyingly still present or not requires careful consideration. The presence of trivocalic systems in Amuesha and Upper Perené Ashéninka (Adelaar, 2006; Adelaar, 2012a: 603), Arawakan languages of the eastern slopes, is evidence for Quechuan's ability to exert influence on languages outside the Andes proper. It also supports a view that does not draw sharp boundaries between Andean and Amazonian linguistic zones, but not a view conceptualizing trivocalic systems as decidedly "Andean" as opposed to "Amazonian."

5 With the characteristic contrast between palatal liquids $/ \eta /$ and $/ K /$, Quechumara could have influenced languages of the eastern slopes, such as Shiwilu (Valenzuela, 2015: 31). 
The characterization of the Andean language type as featuring "fricatives rather than affricates" remains mysterious, for it is not true of any language of the region (at least as defined here), including Quechuan and Aymaran varieties and their respective proto-languages, that it lacks affricates (though the Puquina case remains somewhat unclear).

\subsection{Individual Morphosyntactic Typological Features (c-g)}

In the domain of individual morphosyntactic properties, Aikhenvald's (2007) characterization of Andean languages has similarly mixed success when evaluated for the other reasonably well-documented languages of the area.

In fact, the statement that Andean languages have " $[\mathrm{n}] \mathrm{o}$ genders or classifiers" (feature $(c)$ ) reveals a clear Quechumara bias: Chipaya and Cholón have gender systems (for Chipaya, cf. 1c; in Cholón, the gender distinction is manifest only in the $2^{\text {nd }}$ person singular possessive and verb prefixes), and both Mochica and Cholón have a well-developed set of numeral classifiers (which may have exerted mutual influence on one another, as argued by Eloranta, 2017).

An "[e]xtensive set of core and oblique case markers" (feature $(d)$ ) is found in Quechuan, Aymaran, and Puquina, in the last of which some are borrowed from Quechuan (Adelaar and van de Kerke, 2009:133). Chipaya, too, has a large set of cases (again, some apparently borrowed from Quechuan), though not for core grammatical roles (Adelaar with Muysken, 2004: 367). The same situation obtains in Cholón. Mochica has traditionally been described as also having a case system (though not as extensive as that of the aforementioned languages), but the status of the respective markers regarding morphosyntactic boundness (i.e. whether they are suffixes or postpositions) is again unclear; it is possible that there was only a basic direct vs. oblique (the latter of which traditionally called "genitive") opposition, the remaining "cases" being postpositions (see 1e for illustrations). In addition, as in Chipaya and Cholón, core cases are not marked overtly in normal syntactic contexts (Hovdhaugen, 2004: 21). Table 2 gives an overview of case markers in the languages or language groups, with Quechuan represented by Ayacucho Quechua and Aymaran by the situation that is reconstructed to the proto-language (sources: Cerrón-Palomino, 2000: 213 for proto-Aymara; Soto Ruiz, 1976: 75 for Ayacucho Quechua; Alexander-Bakkerus, 2005: 135-142 for Cholón; Cerrón-Palomino, 2006: 122-130 for Chipaya; Adelaar and van de Kerke, 2009: 133 for Puquina). Markers that are presumably borrowed are in bold. As usual, a compilation of this kind encounters some terminological difficulties (see Table notes); if case markers are assigned the same morpho-semantic function, it should not be taken to mean that they are semantically isomorphic and share all micro-functions. 
TABLE 2 A comparison of case markers in selected Central Andean languages.

\begin{tabular}{|c|c|c|c|c|c|}
\hline & $\begin{array}{l}\text { proto- } \\
\text { Aymara }\end{array}$ & $\begin{array}{l}\text { Ayacucho } \\
\text { Quechua }\end{array}$ & Cholón & Chipaya & Puquina \\
\hline 'nominative' & $*-\emptyset$ & $-\emptyset$ & - & - & - \\
\hline 'ergative' & - & - & - & - & $-s$ \\
\hline 'accusative' & ${ }^{*}$-ha & $-t a$ & - & - & $-c \sim-x$ \\
\hline 'genitive' & *-na & $-p a$ & - & $-t \sim-\emptyset \sim-(i) z h$ & - \\
\hline 'allative' & ${ }^{*}-\mathrm{ru}^{\mathrm{a}}$ & $-m a n^{\mathbf{a}}$ & $-p i$ & $-k i z(i),-k i n(a)^{\mathrm{a}}$ & $-g u t a(c)$ \\
\hline 'benefactive' & ${ }^{*}$-taki & $-p a q^{b}$ & $-h e$ & -ta-japa & $-u a$ \\
\hline 'locative' & ${ }^{*}$-na & $-p i$ & $-t e^{\mathrm{c}}$ & $-k i z(i),-k i n(a)$ & $-n a,-u t$ \\
\hline 'ablative' & $*_{-}-\mathrm{t}^{\mathrm{h}} \mathrm{a}$ & -manta & $-(a) p$ & $-k i z \tan (a)$ & $\begin{array}{l}-c h,-(\text { hua }) \\
\operatorname{nana}(c)\end{array}$ \\
\hline $\begin{array}{l}\text { 'instrumental- } \\
\text { comitative' }\end{array}$ & ${ }^{*}$-na & - wan & $\begin{array}{l}\text {-pat (instrumental); } \\
\text {-nik (comitative) }\end{array}$ & $-\tan (a)$ & $-m$ \\
\hline 'comparative' & *-hamu & - & $-(m i) n^{y}$ & $-z h t a$ & $-g u i$ \\
\hline ‘causative’ & *-layku & $-r a y k u^{\mathrm{d}}$ & $-n a k e^{\mathbf{e}}$ & -layku ${ }^{d}$ & -vichna \\
\hline 'limitative' & *-kama & $-k a m a^{\mathrm{f}}$ & $-l e^{\mathrm{g}}$ & -kama & -cama \\
\hline 'inessive' & - & - & $-m a n$ & - & - \\
\hline 'prolative' & - & - & -nayme & - & - \\
\hline 'dative’ & - & $-p a q$ & - & $-k i z(i)$ & - \\
\hline 'distributive' & - & $-n k a$ & - & - & - \\
\hline 'interactive' & - & -pura & - & - & -pura \\
\hline
\end{tabular}

a called 'illativo' by Cerrón-Palomino (2000) and Soto Ruiz (1976). Cerrón-Palomino's label for Chipaya is 'dativo-ilativo'; indeed, one of the functions of the case in that language is to code the recipient or experiencer with appropriate verbs

b called 'dativo' by Soto Ruiz (1976)

c called 'non-personal adessive' by Alexander-Bakkerus (2005); there also is a 'personal adessive' -tu

d called 'causal' by Cerrón-Palomino (2006) and Soto Ruiz (1976)

e called 'perlative' by Alexander-Bakkerus (2005: 138)

f called 'terminativo' by Soto Ruiz (1976)

g called 'terminative' by Alexander-Bakkerus (2005: 136)

As can also be seen in examples 1a, 1b, and if in section 3.1, Quechuan, Aymaran, and Cholón mark two core arguments on the verb, as Aikhenvald's (2007) feature $(e)$ states (though, as we have seen, the first two by means of suffixes, the last by means of prefixes). As such, these three fit an "Andean" characteristic 
identified by Aikhenvald. Chipaya has clitics expressing "person, gender and number of the subject", which are "normally attached to a non-case-marked expression that accompanies the verb (preferably the object or an adverb, occasionally the subject)" (Adelaar with Muysken, 2004: 367). It therefore cannot be said that there is any verbal person marking proper at all. Again, as discussed, the morphosyntactic status of Mochica personal reference markers is not clear-cut, and it is quite possible that the language had no verbal person marking whatsoever. Even if they were treated as suffixes, however, only one argument would be marked.

With respect to the alignment system, Quechuan and Aymaran languages do indeed have "[f] ully nominative/accusative systems", as Aikhenvald (2007) says in feature $(f)$. Again, the situation becomes significantly less clear when the other Central Andean languages are examined. As Adelaar (2012a: 611) says, "Puquina has a possible accusative marker, which is not consistently used in the only source for that language (Oré, 1607)", but has ergative features otherwise. Alignment in Mochica is subject to various interpretations. The view that a nominative-accusative case system operated in the language (Adelaar with Muysken, 2004) perhaps follows too closely the possibly misleading terminology employed in the colonial grammar by de la Carrera (1644). Alternative proposals include a kind of split-ergativity (Hovdhaugen, 2004: 75) and a hierarchical system (Torero, 2002: 351-357).

As far as feature $(g)$ is concerned, the exclusively suffixing Quechumara type is restricted. Other Central Andean languages also have a clear suffixing preference, the most obvious divergence from this being Cholón, with its characteristic prefixal verbal argument marking apparatus (cf. 2f). But prefixes are also found in the other non-Quechuan, non-Aymaran languages, even though they are not frequent and are of limited importance in the grammar of the languages. Chipaya has two restricted prefixes for personal and impersonal reference respectively (Cerrón-Palomino, 2006: 109), Puquina a verb prefix indicating repetition or restitution of an earlier state of affairs (Adelaar and van de Kerke, 2009: 130), while Mochica appears to have an intensifying prefix can-. It is also possible that pir 'without', traditionally classified as the language's sole preposition, may have been a prefix (Hovdhaugen, 2004: 59, 69). Adelaar (2012a: 607-608), while noting difficulties with the definition of a suffixing preference, observes that "[i]t may very well be that languages such as [...] Puquina developed towards a $100 \%$ suffixing language type by losing their prefixes under areal pressure or by upgrading them to the level of clitics or free forms." Apart from Cholón, prefixing is thus marginal or inexistent in the languages of the Central Andes with substantial documentation, which is at least arguably an areal effect. Nevertheless, given the general suffixing preference on a global 
scale (Cutler et al., 1985) and the particular suffixing preference in the Americas, the fact that even a few prefixes are found seems significant.

\subsection{Lexicon (Feature $(\mathrm{h})$ )}

Finally, regarding the lexicon, all sufficiently documented languages of the Central Andes have, as Aikhenvald correctly points out, a well-developed set of numbers, which are organized on a decimal basis. This is indeed "one of the major points of distinction between the languages of the Andean highlands and the Amazonian languages" (Adelaar, 2012a: 613). It is well to observe, however, that the Aymaran numerals from 1-10 conserve evidence of a subaltern quinary pattern of organization, as Cerrón-Palomino (2000: 200) and Urton (2014: 218) observe independently. The relevant forms from Muylaque Aymara can be seen in Table 3 (Coler, 2014: 601):

Cerrón-Palomino (2000: 199) reconstructs *qallqu as the original word for 'five', surviving in the forms for 'seven' and 'eight', which are composite (phisqa is a loan from Quechua).

\subsection{Evaluation}

The discussion in sections 3.1 to 3.4 shows that, while there is some evidence for embeddedness of Quechumara structures in a larger Central Andean picture, it is better for the time being to regard the Quechumara phenomenon as an extremely interesting case of multilayered bilateral language contact; it fully deserves all the attention it receives, but at the same time it is only to a limited extent representative of the Central Andes, let alone the Andes generally, from

TABLE 3 Muylaque Aymara numerals from 1 to 10.

\begin{tabular}{ll}
\hline maya & ma 'one' \\
paya & pa 'two' \\
kimsa & kinsa 'three' \\
pusi & 'four' \\
phisqa & 'five' \\
suxta & 'six' \\
paqallqu & 'seven' \\
kimsaqallqu & 'eight' \\
llatunka & 'nine' \\
tunka & 'ten' \\
\hline
\end{tabular}


the perspective of areal linguistics. To my knowledge, Torero (2002: 518-522) is the only author to consider a dedicated Quechumara linguistic area, pointing out that this contact complex was surrounded by languages with different characteristics. Van de Kerke and Muysken (2014: 126) sum this up succinctly: "The other Andean languages clearly have separate structural profiles" from Quechuan and Aymaran. Indeed, the evaluated features at best result in a category held together by family resemblances, with Quechuan and Aymaran coming out as the "most Andean" languages and others gradually and to varying degrees diverging from a (preconceived) Quechumara-based prototype.

Recent work appears to confirm a scenario with greater typological variability in the Central Andes. The northern languages Mochica and Cholón are particularly relevant. In Torero's (2002: 536) areal evaluation, Mochica is classified as standing apart from any areal grouping, while he notes that if anything it patterns with languages of Chile and Argentina, such as Mapudungun, Huarpe, Atacameño, and also shows some similarities with languages of the Ecuadorian-Colombian area. Cholón also stands apart for Torero, but has some similarities with Amazonia as regards morphosyntactic behavior. These views are echoed by other studies: Adelaar (2008: 26), for instance, calls Mochica "typologically anomalous" in the Central Andean context. In spite of some limited Quechuan influence in the lexicon (cf. Cerrón-Palomino, 1989), Mochica maintained a typological profile distinct from that of Quechumara. Van de Kerke and Muysken (2014: 141) observe that "the completely different typological make-up of Mochica makes it into an outlier [sic!]" and that "Cholón is also much less 'Andean' than sometimes suggested, despite obvious Quechua borrowings." Indeed, in Van Gijn's (2014: 116) NeighborNet in Fig. 5.1. -which incidentally also shows a close cluster of Quechuan and Aymaran, widely distanced from the other studied languages- Cholón clearly appears in an "Amazonian" part of the network in-between Arawakan languages and Muniche.

Greater typological variation is not just apparent in the North-Central Andes, where Mochica and Cholón were spoken, but also becomes visible at more finegrained resolutions in the south of Peru and Bolivia. Adelaar (2017) speaks of "important typological differences" between Chipaya and Quechumara. Nevertheless, there is evidence for Aymaran influence on Uru-Chipayan languages. Muysken (2000) considers evidence to suggest that the Uru language has been remodeled on the basis of an Aymaran template. Of particular relevance is the fact that there are instances of head-initial compounds in the language which coexist with head-final ones, suggesting that the former represent the initial Uru pattern, and the latter an adaptation to Aymara. Further, as Adelaar (2012a: 605) says referring to Ronald Olson and Liliane Porterie, "glottalized 
consonants in Uru-Chipayan may represent a case of diffusion from Aymaran because of their low frequency." ${ }^{\prime 6}$ A close examination of the features suggested by Aikhenvald (2007), which was carried out in the previous sections, suggests that Puquina, too, has assumed some Quechumara characteristics, and is linked quite closely with the Quechumara typological profile - a situation that is not unexpected on geographical and historical grounds (cf. e.g. CerrónPalomino, 2010). Moreover, it would appear from both Adelaar's (2012a) discussion of the distribution of features and Michael et al.'s (2014) computational (Bayesian) analysis that the Quechumara type has the closest ties with the southern highland languages -besides Puquina, in particular Uru-Chipayabut also more widely with Atacameño and Mapudungun in northern Chile. ${ }^{7}$

In sum, there is no question that there was language contact between Quechuan, Aymaran and the "minor" languages Mochica, Cholón, Chipaya, and Puquina. This can be inferred at least from lexical borrowing, in many cases also borrowing of grammatical markers (cf. in particular the discussion of case

6 Aymaran influence is also hypothesized for an early stage of Quechuan (e.g. Adelaar, 2010). At a later stage, more local influence in the southern Peruvian varieties of Quechuan is clearly seen, for instance in the presence of glottalized consonants in Cuzco Quechua. The latter are not reconstructable to proto-Quechua and likely spread from Aymara through a variety of mechanisms and symbolic associations (Mannheim, 1991).

7 According to Adelaar (2012a), other features that some or all Quechuan and Aymaran varieties share with Puquina are contrastive vowel length (perhaps), inverse markers, the location of subject markers relative to tense markers, and four grammatical persons. Traits shared with Uru-Chipaya include contrastive vowel length, a retroflex affricate, switch reference, four grammatical persons, and case stacking. Case stacking and four grammatical persons are also shared with Cholón, according to Adelaar (2012a), together with the "importance of nominalization." Another commonality not mentioned explicitly by Adelaar (2012a) is switch reference. Proto-Aymara shares with both Cholón and Mochica the velar nasal (only weakly present in the Aymaran languages today and with limited contrastive power). Quechumara features also shared with Mochica, according to Adelaar (2012a), are contrastive vowel length and case stacking; however, the contrastive value of vowel length in Mochica is unclear and the phenomenon is unevenly distributed in Quechuan, making any claim for mutual influence difficult to defend. In addition, Mochica "cases" can mostly be analyzed as cliticizing postpositions and "case stacking" as clitic chains (Urban, 2019). Quechuan, Aymaran, and Mochica in addition mark the dependent in possessive phrases (Quechuan and Aymaran also the head). In sum, I interpret the evidence presented in Adelaar (2012a) to support the idea that Quechumara structures have stronger similarities with the languages of the southern highlands, viz. Uru, Chipaya, and Puquina, than with Mochica and Cholón, even though there is some resemblance in certain aspects of the grammatical system, in particular with Cholón. Note that, in contrast, Torero (2002: 535-536) treated Uru-Chipaya, Puquina, and Atacameño and Huarpe in Northern Argentina as making up an "altiplano" area separate from Quechuan and Aymaran, and Mapudungun as a separate language. 
markers in section 3.3), and -at least in the case of Chipaya- also some possible structural interference. Yet, this does not mean that these languages formed a language area together with Quechuan and Aymaran languages as regards (all) the features evaluated in section 3. On the contrary, it would appear that three factors led to a situation in which Quechumara characteristics influence ideas of what Andean languages are like to a disproportionately high degree (cf. Torero, 2002: 518): First, the sheer numeric superiority of distinct Quechuan and Aymaran varieties, second, the saliency they have achieved in the scholarly community because of the intensive attention given to their complex mutual relationship, and third, the relatively poor state of knowledge regarding the above-mentioned "minor" languages that obtained until very recently. Attempt

Consideration of Central Andean linguistic diversity has so far suggested a bias towards Quechumara in terms of structural characteristics that are considered typical for the area. Undoing this bias to the extent possible paints a more nuanced picture.

Yet there are two other biases that stand in the way of a fair areal-typological consideration of the area in its entirety. One is the extinction bias. Reflecting the dominance of Quechuan and Aymaran in scholarly discourse on the linguistic diversity of the Andes, Adelaar (2012a: 576) characterizes the Central Andes as an area "with an originally high genetic diversity that achieved an apparent uniformity through the dominance of just a few of its endemic language groups (Quechuan and Aymaran) and an intrusive language (Spanish)." As described in section 2.2., prior to events leading to language shift in late preHispanic and colonial times, the linguistic landscape was significantly more complex.

The extinction bias leads to a third, geographical, bias, as the North-Central Andes were hit harder by language loss than the southerly region: the isolated islands of Quechuan in the highlands of the Lambayeque department, the Cajamarca region, and the area of Chachapoyas are the only indigenous languages surviving to the present day in the North-Central Andes.

However, research on the original linguistic diversity of the North-Central Andes is now in a state that is mature enough -bearing in mind the generally unsatisfactory level of documentation and the consequence that it is never as good as one would wish- to allow for a comparative treatment of North-Central languages. This cannot be done in the same fashion as typological comparisons 
for Quechumara because, with the exception of Mochica and Cholón, little can be known about the structures and typological characteristics of the northern languages. It is therefore not possible to compare alignment, word order regularities, the structure of the noun phrase, or, for that matter, any other grammatical phenomena that require the availability of grammatical descriptions. Nevertheless, this does not mean that the North-Central languages must remain outside the scope of areal-typological investigations, as phenomena that are observable through words in isolation -phonotactic patterns, root canons, and even some morphological traits- can be, if only tentatively, be put in a comparative perspective. Here, comparative linguistics, which has recently moved more and more into computational and quantitative terrain, must reestablish contact with its philological roots.

What, then, would the areal-typological picture look like if data for all these languages were available in sufficient quantity and quality? Torero (2002: 534) actually says that his typologically "independent" languages, Mochica and Cholón among them, perhaps once formed parts of areas that today are no longer recognizable. In fact, Torero (2002: 212) himself has already noted one areal trait characterizing the languages of the North Coast and northern highlands that were documented by Martínez Compañón ([1782-1790]1985), namely Tallán, Sechura, Mochica, Culli, Hibito, Cholón: it is a greater frequency of monosyllabic words in these languages, as opposed to the Quechua and Spanish data also contained in the document. His counts are shown in Table 4.

Torero sometimes even underestimated the frequency of monosyllables, since he apparently did not conduct a very detailed morphological analysis

TABLE 4 Percentages of monosyllabic items in Martínez Compañón's ([1782-1790]1985) wordlists of languages of the northern Peruvian Andes, according to Torero (2002: 212).

\begin{tabular}{ll}
\hline Language & Percentage \\
\hline Mochica & $68.5 \%$ \\
Cholón & $39.5 \%$ \\
Tallán (Colán variety) & $33.3 \%$ \\
Tallán (Catacaos variety) & $25.0 \%$ \\
Hibito & $24.3 \%$ \\
Sechura & $23.5 \%$ \\
Culli & $21.1 \%$ \\
Spanish & $11.1 \%$ \\
Quechua & $0 \%$ \\
\hline
\end{tabular}


of the material. For instance, in Sechura he failed to identify various suffixes, most importantly the very common "infinitive" <-uc > in that language (Urban, 2019). As far as Quingnam is concerned, it can be noted that regional vocabulary in local Spanish, for which the language must have formed a substrate, appears consistent in structure with this trait (Urban, 2019). Even more relevant is that, although the language is virtually undocumented, it is possible to actually observe how Quechuan disyllabic material was adapted phonotactically in language contact. In the Magdalena de Cao numeral list (Quilter et al., 2010), the Quechua II numerals tawa 'four' and suqta 'six' were adapted to the phonology of the native North Coast language as $<$ tau $>$ and $<$ sut $>$ respectively (the latter is a tentative transcription). This strongly suggests a root shape canon in Quingnam that differs from the disyllabic Quechuan pattern. Regarding the "Den" and "Cat" toponyms, it is also possible to note the existence of monosyllabic first constituents of placenames (and, of course, the eponymous recurrent endings also fit the pattern). Quantitatively, however, it is hard to speak of a preference, as disyllabic elements are also numerous. ${ }^{8}$ Personal names from colonial Chachapoyas (Taylor, 1990) and lexical items that can be isolated from toponyms such as $<-$ cot $>$ and $<$-lap $>$ strongly suggest that the Chacha language aligned with its northern neighbors as regards a notable presence of monosyllabic roots. "Northern monosyllabism" must be a relatively old typological trait, if it is true that toponyms ending in -is, widely distributed on the coastal fringe, are an indication of a linguistic stratum predating that of the early $16^{\text {th }}$ century, as Torero (1989) suggests: the first element of these toponyms is nearly always monosyllabic. The greater frequency of monosyllabic roots is in sharp contrast with the Quechumara root canon, which strongly prefers lexical roots of more than one syllable. In Quechuan, the number of monosyllabic verbs can be counted with the fingers of one hand. ${ }^{9}$ Aymara roots are generally disyllabic or trisyllabic. Even though disyllabic roots are evidently permitted as well in the northern languages, the strict Quechumara root structure canons contrast clearly with the situation in the northern languages. One can theorize (though

8 One must bear in mind that the toponyms are all filtered through the phonology and phonotactics of Spanish, and many of them were previously filtered through Quechua in the same way (see Andrade Ciudad, 2010 for a stratigraphy of language replacement in the northern highlands). This could have resulted in vowel epenthesis obscuring original root shape preferences.

9 Internal evidence suggests that at a very early stage of development, Quechuan relied on monosyllabic roots to a much greater extent. This topic is currently being investigated by Nicholas Emlen. If higher levels of monosyllabicity in pre-proto-Quechua can be substantiated, this would be another point in support of the idea that the Quechuan family has a northern origin. 
not conclusively prove) that substrate influence from Chacha, resulting from language shift of its erstwhile speakers to Quechua, might account for some of the remarkable phonological changes that Chachapoyas Quechua underwent after separation from its direct ancestor Chachapoyas-Lamas Quechua, which typologically is still "well-behaved" from a Quechuan perspective. These changes saliently include the reduction of unstressed vowels, which leads to a (surface) monosyllabification of disyllabic Quechua roots (this is probably causally related to shift of stress to the first syllable; see Taylor, 1994: 24-25 for further details). However, the contrast with non-Quechumara languages in the south is less pronounced: Chipaya and Puquina both show no clear preference for either mono- or disyllabic roots and in this regard resemble the northern languages more than their immediate Quechuan and Aymaran neighbors.

A further property that the languages of the North share with one another, but less with Quechuan and Aymaran, is the tolerance of plosives in word-final position. This trait is seen clearly in the available data for Tallán, Sechura, Mochica, Culli and Cholón, and can be safely assigned to Quingnam and Chacha on the basis of placenames and personal names; it is also strongly supported by the Magdalena de Cao list of numerals. In Quechuan, $/ \mathrm{t} /$ is not permitted wordfinally, and $/ \mathrm{p} /$ is rare and arguably the result of fossilized suffixation (Willem Adelaar, p.c.). $/ \mathrm{k} /$ and $/ \mathrm{q} /$ are allowed (although in some varieties they fricativize in syllable-final position). Aymara categorically prohibits final plosives underlyingly, but they may feature on the surface as the result of a complex set of vowel reduction rules. There is no evidence for any of the Northern languages that their final plosives are the result of such rules, although for the particularly poorly documented ones this cannot be conclusively ruled out either. ${ }^{10}$ Relevantly, Pache (2011) argues that a subset of V-final roots in present-day Quechuan varieties were probably still C-final in proto-Quechua, and adapted to an Aymaran root canon. Puquina, like the northern languages, allowed word-final plosives (though they appear to be less frequent here). In Chipaya, plain stops can occur finally; however, in proto-Uru-Chipaya, at the level of the root, final consonants are categorically disallowed (Cerrón-Palomino, 2007: 64).

There is thus some evidence that there are pertinent typological features which some Northern languages share among themselves. To a lesser degree, these are also found in the south, though importantly more clearly in the "minor" languages, and not so prominently in Quechuan and Aymaran. In this

10 It is interesting to note that in both respects Quechua resembles the northern languages somewhat more than Aymara. 
sense, the evidence with regard to these features suggests that Quechuan and Aymaran languages, rather than being typical representatives of the Central Andean languages, may actually be rather poor ones; this is also true with regard to other properties, as shown in section 2 , such as the trivocalic system in segmental phonology. ${ }^{11}$

For some of the northern languages, however, there is also evidence for similarities with Quechuan and Aymaran. In Culli and Chacha, for instance, there is evidence for a velar-uvular opposition. For Culli, the assumption is fueled by the presence of a peculiar diacritic in the shape of an asterisk in Martínez Compañon's $([1782-1790] 1985)$ data, which correlates statistically with the presence of mid-vowels (Adelaar with Muysken 2004: 402). For Chacha, the presence of uvulars is suggested by the usage of $\langle\mathrm{cc}\rangle$ in the spelling of personal names in colonial documents. This digraph typically represents uvulars in colonial materials of Quechuan and Aymaran (Adelaar, 2012a: 604). A similar correlation between letters representing back consonants and mid-vowels can be observed for Tallán, in particular personal names, but with less consistency (Urban, 2019). As far as one can tell from the available data, it seems that the Culli language resembled Quechumara most strongly from a phonological point of view, in that the hypothesized uvular appears to have had the same lowering effect on high vowels as in Quechumara.

Thus, it appears again that there were no sharp boundaries between the Northern and Southern Central Andes, with areas "flowing into each other", to use Dixon and Aikhenvald's (1999) formulation. The evidence to this effect pertains in particular in those languages of the northern region that would have been geographically closest to Quechuan varieties: Culli and Cholón.

\section{General Discussion}

This article has raised a number of points related to the areal typology of the Central Andes, which are also relevant for conceptions of linguistic areality in South America more broadly. The perceived structural homogeneity of

11 That said, the features are not typologically uncommon or "unnatural" in any relevant sense, so that no strong claim as to contact influence can be made (note, however, that syllable structure constraints are among the features characteristically borrowed at fairly intense levels of language contact; see Thomason, 2001: 70). Note also that there are no relatives of the Northern Peruvian languages outside that area that could serve as controls. Nevertheless, the contrast with Quechumara canons remains significant. 
the Central Andean languages appears to derive in large part from ancient structural convergence between early precursors of the major language families, Quechuan and Aymaran, and continuing contact between some of the daughter languages. The data presented here on the North-Central Andes also show that one must assume that some areal effects have probably been buried by language extinction. In order to partially recover these, there is no way to avoid philological work on the kind of materials evaluated in section 3 .

"[H]ighly skewed towards the Quechua data" is how van de Kerke and Muysken (2014: 141) describe their own sample of Andean languages. The discussion presented in this article suggests that, if the quest for common linguistic features of the Central Andean languages were to start out from the full linguistic diversity of the area, treating Quechuan and Aymaran as two language families among many others, the emerging picture would differ in some crucial respects. A related point to bear in mind is that linguistic areality by definition is the result of convergence due to the horizontal transmission of features rather than their vertical transmission from a common ancestor at some level of time-depth. And yet, the fact that traits shared between many Quechuan varieties are often due to common descent and hence irrelevant for areal studies is often treated quite tacitly. When this teams up with the above-discussed biases towards Quechumara, it can lead to results that must be interpreted carefully. For instance, Michael et al.s (2014) study seemingly confirms Aikhenvald's characterization of Andean languages as a whole as having trivocalic vowel systems. However, the trivocalic system of most Quechuan and Aymaran varieties reconstructs to both protolanguages. There are therefore two datapoints from an areal perspective here, not twenty-two (or however many Quechuan varieties one includes in the study).

Otherwise, the examination of Quechumara structures in relation to the linguistic diversity of the Central Andes in section 2, and the discussion of similarities in phonotactics among the northern languages in section 3, open up two main lines of interpretation: one would be that the Central Andes hosted two distinguishable but interlocking linguistic areas, one northern and one southern. These would closely correspond at the geographical and possibly also at the causal level to the hotspots of cultural developments in the preHispanic Central Andes in the narrow sense used in this article. These, like the linguistic areas, were nevertheless linked to one another. This picture could be reconciled with the results of Michael et al.'s (2014) computational evaluation of phonological characteristics of the languages of the Andes and their fringe areas. These authors, after an initial treatment with pan-Andean scope, offer 
arguments for an analysis of the same broad region that operates with two cores, separating languages of the Northern Andes from the Southern Andes at the latitude of present-day southern Peru. ${ }^{12}$ Another possible interpretation is that Quechumara is really a special phenomenon resulting from intense bilateral language contact that caused the (proto-)languages involved to drift away from a more generalized Central Andean typological region. This view would be based in particular on the fact that the northern languages differ rather drastically from Quechumara canons, but not ostensibly from the "minor" languages of the south, like Chipaya and Puquina.

To settle the question, an important task would be a well-founded stratification of similarities and dissimilarities of the languages of the Central Andes. It is clear that Quechuan influence on languages of the eastern slopes and lowlands, such as Amuesha (Adelaar, 2006), postdates the establishment of the first contact between Quechuan and Aymaran. Absolute dating in historical linguistics is notoriously difficult; Quechuan is usually assigned a time-depth roughly comparable to Romance, which would indicate a split-up date of roughly 2,00o years in the past. This would provide an approximate estimation of the antiquity of the Quechumara phenomenon and hence any influence on other Andean languages, such as Amuesha.

Then, there are the broader similarities with regions peripheral to the precocious cultural developments in the Central Andes, in particular the Chaco. Evidence from Adelaar (2012a) and Michael et al. (2014) also points to a lack of clear areal boundaries, particularly in the south and southeast. Glottalized consonants and the velar-uvular distinction in fact transcend the Andean area and extend to the Gran Chaco (Adelaar, 2012a). Other features, such as aspiration, and indeed the presence of plain, glottalized, and aspirated series of obstruents, extend to the Southern Cone. "Patagonia and the Chaco constitute an essentially contiguous phonological area with the Southern Andes" (Michael et al., 2014: 49), a conclusion also reached by Torero (2002: 535). Michael et al. (2014: 50) ponder long-distance trade sponsored by the Tiwanaku polity (cf. e.g. Torres-Rouff, 2008), but as they say themselves, "it is unclear whether those relations would have been sufficiently intense to produce the kind of convergence we see between the southern Andean languages." Phoneme borrowing of the kind of systematicity observed here is no trivial matter, and would seem to presuppose the bilingualism among a sufficient subset of speakers of either

12 Michael et al. (2014: 35) also note a different cultural trajectory between the northern and southern regions. However, the scope of their investigation is almost pan-Andean. 
language involved. In fact, it is hard to think of an archaeologically recoverable agent that could be identified as uniting the areas in this way, and the alternative hypothesis of "down-the-line" diffusion of the phonological aspects in question is a costly one, given the vastness of the area involved. Then, if viewed as historically meaningful, these similarities would have to reflect something older than the rise of linguistic areality within the Central Andes themselves, including the Quechumara phenomenon.

The consideration of the Andes is relevant for theories of linguistic areality more broadly. In Amazonia, a multitude of relatively localized areas of linguistic contact and convergence are now recognized. Here, in particular in section 4, I suggest that a similar situation may have once obtained in the Central Andes. Nevertheless, studies on a macro level with very wide scope, such as those of Dixon and Aikhenvald (1999) and Aikhenvald (2007), can still be worth pursuing, as long as they bear in mind that the possible identification of continent-wide areal trends or skewings do not necessarily imply very large, typologically homogeneous monoliths that correspond to the division between "Andes" and "Amazonia." This is not only suggested by the increasingly fine-grained studies of the transition zone (van Gijn, 2014; Michael et al., 2014; Valenzuela, 2015), but also by questionnaire-based typological studies on alignment patterns, such as those by Birchall (2014), which suggest a more general east-west divide that does not, however, reflect the geographical boundaries of the Andes and Amazonia. ${ }^{13}$

As these reassessments progress, a lesson learned in the meantime is that the notion "Central Andean linguistic features" should not be used lightly to mean "Quechuan and Aymaran linguistic features" and vice versa. If scholars use notions like this, they should be aware that areal-typological homogeneity may not be as high, and should be explicit about what they mean when they speak of typological features of the languages of the Central Andes.

13 Another issue, although not of central interest in the context of the present discussion, is that members of the "Andean" Quechuan language family are actually also spoken in the Western Amazonian lowlands of Ecuador and Peru. Quechuan is thus not exclusively a language family of the highlands (cf. also Emlen, 2016). In addition, there is no indication that in terms of overall structure, these varieties differ in significant ways from their respective highland relatives. Dixon and Aikhenvald's (1999: 8-10) own definition of linguistic area, however, includes the criterion that genealogically related languages in and outside a proposed linguistic area should differ with regard to the pertinent features. 


\section{Acknowledgment}

The research leading to this article was funded by the European Research Council under the European Union's Seventh Framework Programme (ERC grant agreement $\mathrm{n}^{\circ}$ 295918). The author is grateful to Willem F.H. Adelaar, Matthias Pache, and an anonymous reviewer for their comments on earlier versions of this article.

\section{References}

Adelaar, Willem F.H. 1999. Unprotected languages: the silent death of the languages of Northern Peru. In Anita Herzfeld and Yolanda Lastra (eds.), Las causas sociales de la desaparición y del mantenimiento de las lenguas en las naciones de América, 205-222. Hermosillo: Editorial Unison.

Adelaar, Willem F.H. 2006. The Quechua impact in Amuesha, an Arawak language of the Peruvian Amazon. In Alexandra Y. Aikhenvald and Robert M.W. Dixon (eds.), Grammars in contact: a cross-linguistic typology, 290-312. Oxford: Oxford University Press. Adelaar, Willem F.H. 2007. The importance of toponymy, family names and historical documentation for the study of disappearing and recently extinct languages in the Andean region. In W. Leo Wetzels (ed.), Language endangerment and endangered languages. Linguistic and anthropological studies with special emphasis on the languages and cultures of the Andean-Amazonian border area, 325-331. Leiden: CNws. Adelaar, Willem. 2008. Towards a typological profile of the Andean languages. In Alexander Lubotsky, Jos Schaeken and Jeroen Wiedenhof, with the assistance of Rick Derksen and Sjoerd Siebinga (eds.), Evidence and counter-evidence: essays in honour of Frederik Kortlandt, vol. 2: general linguistics, 23-33. Amsterdam/New York: Rodopi.

Adelaar, Willem F.H. 2010. Trayectoria histórica de la familia lingüística quechua y sus relaciones con la familia lingüística aimara. In Peter Kaulicke, Rodolfo CerrónPalomino, Paul Heggarty and David Beresford-Jones (eds.), Lenguas y sociedades en el antiguo Perú: hacia un enfoque interdisciplinario. Boletín de Antropología 14 (Special Issue): 239-254.

Adelaar, Willem F. H. 2012a. Languages of the Middle Andes in areal-typological perspective: emphasis on Quechuan and Aymaran. In Lyle Campbell and Verónica Grondona (eds.), The indigenous languages of South America: a comprehensive guide, 575-624. Berlin/Boston: Walter de Gruyter.

Adelaar, Willem F.H. 2012b. Modeling convergence: towards a reconstruction of the history of Quechuan-Aymaran interaction. Lingua 122 (5): 461-469. DOI: 10.1016/j. lingua.2011.10.001. 
Adelaar, Willem F.H. 2013. Quechua I y quechua II: en defensa de una distinción establecida. Revista Brasileira de Lingüística Antropológica 5 (1): 45-65.

Adelaar, Willem F.H. 2017. A typological overview of Aymaran and Quechuan language structure. In Alexandra Y. Aikhenvald and Robert M. W. Dixon (eds.), The Cambridge Handbook of Linguistic Typology, 651-682. Cambridge: Cambridge University Press.

Adelaar, Willem F.H., with the collaboration of Pieter C. Muysken. 2004. The languages of the Andes. Cambridge: Cambridge University Press.

Adelaar, Willem and Simon van de Kerke. 2009. Puquina. In Mily Crevels and Pieter Muysken (eds.), Lenguas de Bolivia, vol. 1, 125-146. La Paz: Plural Editores.

Aikhenvald, Alexandra Y. 2002. Language contact in Amazonia. Oxford: Oxford University Press.

Aikhenvald, Alexandra Y. 2007. Languages of the Pacific Coast of South America. In Osahito Miyaoka, Osamu Sakiyama, and Michael E. Krauss (eds.), The vanishing languages of the Pacific Rim, 183-205. Oxford/New York: Oxford University Press.

Alexander-Bakkerus, Astrid. 2005. Eighteenth-century Cholón. Utrecht: LOT.

Alva Meneses, Ignacio. 2008. Los complejos de Cerro Ventarrón y Collud-Zarpán: del precerámico al formativo en el valle de Lambayeque. Boletín de Arqueología 12: 97-117.

Andrade Ciudad, Luis. 2010. Contactos y fronteras de lenguas en la Cajamarca prehispánica. In Peter Kaulicke, Rodolfo Cerrón-Palomino, Paul Heggarty and David Beresford-Jones (eds.), Lenguas y sociedades en el antiguo Perú: hacia un enfoque interdisciplinario. Boletín de Antropología (Special Issue) 14: 165-180.

Birchall, Joshua. 2014. Verbal argument marking patterns in South American languages. In Loretta O'Connor and Pieter Muysken (eds.), The native languages of South America: origins, development, typology, 223-249. Cambridge: Cambridge University Press.

Campbell, Lyle. 2006. Areal linguistics: a closer scrutiny. In Yaron Matras, April McMahon, and Nigel Vincent (eds.), Linguistic areas: convergence in historical and typological perspective, 1-31. Basingstoke/New York: Palgrave Macmillan.

Campbell, Lyle, Terrence Kaufman, and Thomas C. Smith-Stark. 1986. Mesoamerica as a linguistic area. Language 62 (3):530-570. DOI: 10.2307/415477.

Carrera, Fernando de la. 1644. Arte de la lengva yvnga de los valles del obispado de Truxillo del Peru, con vn confessonario, y todas las oraciones christianas, traducidas en la lengua, y otras cosas. Lima: Joseph Contreras.

Cerrón-Palomino, Rodolfo. 1987. Lingüística quechua. Cuzco: Centro de Estudios Rurales Andinos 'Bartolomé de las Casas'.

Cerrón-Palomino, Rodolfo. 1989. Quechua y mochica: lenguas en contacto. Lexis 13 (1): 47-68. 
Cerrón-Palomino, Rodolfo. 1994. Quechumara: estructuras paralelas de las lenguas quechua y aimara. La Paz: Centro de Investigación y Promoción del Campesinado.

Cerrón-Palomino, Rodolfo. 1995. La lengua de Naimlap (reconstrucción y obsolescencia del Mochica). Lima: Fondo Editorial de la Pontificia Universidad Católica del Perú.

Cerrón-Palomino, Rodolfo. 200o. Lingüística aimara. Cuzco: Centro de Estudios Regionales Andinos 'Bartolomé de las Casas'.

Cerrón-Palomino, Rodolfo. 2003. Lingüística quechua. $2^{\text {nd }}$ ed. Cuzco: Centro de Estudios Regionales Andinos 'Bartolomé de las Casas'.

Cerrón-Palomino, Rodolfo. 2006. El chipaya o la lengua de los hombres del agua. Lima: Fondo Editorial de la Pontificia Universidad Católica del Perú.

Cerrón-Palomino, Rodolfo. 2007. Reconstruccion del proto-uro: fonología. Lexis 31 $(1 / 2): 47-104$.

Cerrón-Palomino, Rodolfo. 2010. Contactos y desplazamientos lingüísticos en los Andes centro-sureños: el puquina, el aimara y el quechua. In Peter Kaulicke, Rodolfo Cerrón-Palomino, Paul Heggarty, and David Beresford-Jones (eds.), Lenguas y sociedades en el antiguo Perú: hacia un enfoque interdisciplinario. Boletín de Antropología 14 (Special Issue): $255^{-282}$.

Cerrón-Palomino, Rodolfo and Enrique Ballón Aguirre. 2011. Chipaya. Léxico Etnotaxonomía. Nijmegen: Radboud Universiteit Nijmegen, Centre for Language Studies/Lima: Fondo Editorial de la Pontificia Universidad Católica del Perú.

Coler, Matt. 2014. A grammar of Muylaq' Aymara: Aymara as spoken in Southern Peru Leiden: Brill.

Comrie, Bernard. 1989. Language universals and linguistic typology: syntax and morphology. $2^{\text {nd }}$ ed. Chicago: University of Chicago Press.

Cutler, Anne, Stephen A. Hawkins, and Gary Gilligan. 1985. The suffixing preference: a processing explanation. Linguistics 23: 723-758. DoI: 10.1515/ling.1985.23.5.723.

Dixon, Robert M. W. and Alexandra Y. Aikhenvald. 1999. Introduction. In Robert M. W. Dixon and Alexandra Y. Aikhenvald (eds.), The Amazonian languages, 1-21. Cambridge: Cambridge University Press.

Durston, Alan. 2007. Pastoral Quechua: the history of Christian translation in colonial Peru, 1550-1650. Notre Dame: University of Notre Dame Press.

Eloranta, Rita. 2017. Language contact across the Andes: the case of Mochica and Hibito-Cholón. In Karen Dakin, Claudia Parodi, and Natalie Operstein (eds.), Language contact and change in Mesoamerica and beyond, 319-334. Amsterdam/ Philadelphia: John Benjamins.

Emlen, Nicholas Q. 2016. Multilingualism in the Andes and Amazonia: a view from in-between. Journal of Latin American and Caribbean Anthropology. DoI: 10.1111/ jlca.12250. 
Emlen, Nicholas Q. 2017. Perspectives on the Quechua-Aymara contact relationship and the lexicon and phonology of Pre-Proto-Aymara. International Journal of American Linguistics 83 (2): 307-340. DOI: 10.1086/689911.

Epps, Patience. In press. Amazonian linguistic diversity and its sociocultural correlates. In Mily Crevels and Pieter Muysken (eds.), Language dispersal, diversification, and contact: a global perspective. Oxford: Oxford University Press.

Greenberg, Joseph H. 1960. A quantitative approach to the morphological typology of language. International Journal of American Linguistics 26 (3): 178-194. DoI: $10.1086 / 464575$.

Hardman, M.J. 2001. Aymara. Munich: Lincom Europa.

Hovdhaugen, Even. 2004. Mochica. Munich: Lincom Europa.

Isbell, William H. and Helaine Silverman. 2008. Rethinking the Central Andean Cotradition. In William H. Isbell and Helaine Silverman (eds.), Andean archaeology III: north and south, 497-518. New York: Springer.

Mannheim, Bruce. 1991. The language of the Inka since the European invasion. Austin: University of Texas Press.

Martínez Compañón, Baltasar Jaime. [1782-1790]1985. Trujillo del Perú en el siglo XVIII. Vol. 2. Madrid: Ediciones Cultura Hispánica.

Mason, J. Alden. 1950. The languages of South American Indians. In Julian H. Steward (ed.): Handbook of South American Indians, vol. 6: physical anthropology, linguistics, and cultural geography of South American Indians, 157-317. Washington: United States Government Printing Office.

Michael, Lev, Will Chang, and Tammy Stark. 2014. Exploring phonological areality in the circum-Andean region using a naive Bayes classifier. Language Dynamics and Change 4: 27-86.

Muysken, Pieter. 2000. Drawn into the Aymara mold? Notes on Uru grammar. In Hein van der Voort and Simon van de Kerke (eds.), Indigenous languages of lowland South America, 99-109. Leiden: Research School of Asian, African, and Amerindian Studies (CNWS).

Muysken, Pieter. 2008. Introduction: conceptual and methodological issues in areal linguistics. In Pieter Muysken (ed.): From linguistic areas to areal linguistics, 1-23. Amsterdam/Philadelphia: John Benjamins.

Mata, Pedro de la. [1748]2007. Arte de la lengua Cholona (1748). Ed. by Astrid AlexanderBakkerus. Madrid/ Frankfurt am Main: Iberoamericana/Vervuert.

Nichols, Johanna. 1986. Head-marking and dependent-marking grammar. Language 62 (1): 56-119. D OI: $10.2307 / 415601$.

Oré, Lvdovicvs Hieronymvs. 1607. Ritvale, sev manvale Pervanvm, et forma brevis administrandi apud Indos sacrosancta Baptismi, Ponitentice, Eucharistice, Matrimonij, \& Extremce vnctionis Sacramenta. Naples: Io. Iacobus Carlinus \& Constantinus Vitalis. 
Pache, Matthias. 2011. Reconstrucción de raíces proto-quechuas mediante una comparación con el mapuche. $3^{\text {rd }}$ Conference of the European Network for the study of Andean languages (RE ELA), Department of Linguistics, Max Planck Institute for Evolutionary Anthropology, Leipzig, Germany, Nov $3^{\text {st }}$ - Dec $1^{\text {st }} 2011$.

Pearce, Adrian J. and Paul Heggarty. 2011. 'Mining the data' on the Huancayo-Huancavelica Quechua frontier. In Paul Heggarty and Adrian J. Pearce (eds.), History and Language in the Andes, 87-109. New York: Palgrave Macmillan.

Quilter, Jeffrey. 2014. The ancient Central Andes. London/New York: Routledge.

Quilter, Jeffrey, Marc Zender, Karen Spalding, Régulo Franco Jordán, César Gálvez Mora, and Juan Castañeda Murga. 2010. Traces of a lost language and number system discovered on the North Coast of Peru. American Anthropologist 112 (3): 357369. DOI: 10.1111/j.1548-1433.2010.01245.x.

Rivet, Paul. 1949. Les langues de l'ancien diocèse de Trujillo. Journal de la Société des Américanistes de Paris 38: 1-51.

Soto Ruiz, Clodoaldo. 1976. Gramática quechua:Ayacucho-Chanca. Lima: Ministerio de Educación.

Stanish, Charles. 2001. The origin of state societies in South America. Annual Review of Anthropology 30: 41-64. DOI: 10.1146/annurev.anthro.30.1.41.

Stolz, Thomas. 2002. No Sprachbund beyond this line! On the age-old discussion of how to define a linguistic area. In Paolo Ramat and Thomas Stolz (eds.), Mediterranean Languages: papers from the MEDTYP Workshop, Tirrenia, June 200o, 259-281. Bochum: Brockmeyer.

Stothert, Karen E. 2013. The peoples of the coast of Ecuador accommodate the Inca state. Ñawpa Pacha 33 (1): 71-102. DOI: 10.1179/0077629713Z.0000000004.

Taylor, Gérald. 1990. La lengua de los antiguos Chachapuyas. In Rodolfo CerrónPalomino and Gustavo Solís Fonseca (eds.), Temas de lingüística amerindia: primer Congreso Nacional de Investigaciones Lingüístico-Filológicas, 121-139. Lima: Consejo Nacional de Ciencia y Tecnología/ Programa de Educación Bilingüe de Puno.

Taylor, Gerald. 1994. Estudios de dialectología quechua (chachapoyas, ferreñafe, yauyos). Lima: Universidad Nacional de Educación.

Thomason, Sarah G. 2001. Language contact. Edinburgh: Edinburgh University Press.

Thomason, Sarah G. 2014. The Pacific Northwest linguistic area. In Claire Bowern and Bethwyn Evans (eds.), The Routledge Handbook of Historical Linguistics, 726-736. Abingdon/New York: Routledge.

Torero, Alfredo. 1986. Deslindes lingüísticos en la costa norte peruana. Revista Andina $4(2): 523-548$.

Torero, Alfredo. 1989. Areas toponímicas e idiomas en la sierra norte peruana: un trabajo de recuperación lingüística. Revista Andina 7 (1): 217-257.

Torero, Alfredo. 1993. Lenguas del nororiente peruano: la hoya de Jaén en el siglo XVI. Revista Andina 11 (2): 447-472. 
Torero, Alfredo. 2002. Idiomas de los Andes: lingüística e historia. Lima: Instituto Francés de Estudios Andinas/Editorial Horizonte.

Torres-Rouff, Christina. 2008. The influence of Tiwanaku on life in the Chilean Atacama: mortuary and bodily perspectives. American Anthropologist 110 (3): 325-337. DOI: 10.1111/j.1548-1433.2008.00042.x.

Urban, Matthias. 2015. El vocabulario sechurano de Richard Spruce. Lexis 39 (2): 395-413.

Urban, Matthias. 2017. ¿Multilingüismo prehispánico en la costa norte del Perú? Una exploración de las evidencias. Umbral 3 (3): 67-88.

Urban, Matthias. 2019. Lost languages of the Peruvian North Coast. Berlin: Gebr. Mann \& Ibero-American Institute.

Urton, Gary. 2012. The herder-cultivator relationship as a paradigm for archaeological origins, linguistic dispersals, and the evolution of record-keeping in the Andes. In Paul Heggarty and David Beresford-Jones (eds.), Archaeology and language in the Andes: a cross-disciplinary exploration of prehistory, 321-343. Oxford: Oxford University Press for The British Academy.

Urton, Gary. 2014. From Middle Horizon cord-keeping to the rise of Inka khipus in the central Andes. Antiquity 88: 205-221. DOI: 10.1017/Sooo3598X00050316.

Valenzuela, Pilar M. 2015. ¿Qué tan “amazónicas” son las lenguas kawapana? Contacto con las lenguas centro-andinas y elementos para un área lingüística intermedia. Lexis 39 (1): $5^{-56 .}$

Van de Kerke, Simon and Pieter Muysken. 2014. The Andean Matrix. In Loretta O'Connor and Pieter Muysken (eds.), The native languages of South America: origins, development, typology, 126-151. Cambridge: Cambridge University Press.

Van Gijn, Rik. 2014. The Andean foothills and adjacent Amazonian fringe. In Loretta O'Connor and Pieter Muysken (eds.), The native languages of South America: origins, development, typology, 102-125. Cambridge: Cambridge University Press. 